\title{
Croatian science looks ahead as it fights for survival
}

Zagreb \& Osijek. Despite the frequent bombardment of laboratories, an insignificant research budget, and a continuing brain drain, Croatian science remains alive. Freed of the communist regime, the government is now planning to establish a new, competitive research system; and Germany is offering to help.

At present, survival rather than strategy is the name of the game. The war in the former Yugoslavia has created a deep economic crisis. Croatia's investment in science has dropped sixfold over the past three years. The $\$ 30$ million spent on research in 1992 - the same as the monthly sum spent supporting its 500,000 refugees - barely covers salaries and journal costs.

The average pay for a scientist has fallen to around $\$ 180$ a month. Croatia's four universities have given up hope of maintaining modern facilities; the department of chemistry at the University of Zagreb last year had only $\$ 30$ per student to spend on chemicals, software and equipment.

The problems facing Croatia's 9,000 or so scientists are not limited to the lack of money. Fighting has caused extensive damage to many research facilities. Worst hit is the University of Osijek in eastern Croatia, founded in 1975. Situated only 800 metres from the front line, its faculty of agriculture

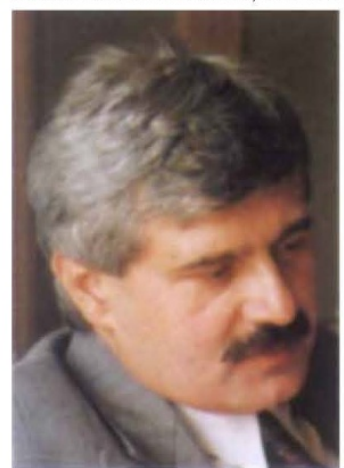

Research minister Jeren is planning reforms and Institute for Food Technology have been under fire for months, and several entire buildings have been destroyed.

Staff and students have been forced to find premises elsewhere in the city. Research has inevitably been badly affected.

But scientists have managed to repair some pieces of equipment, and are trying to continue their work in makeshift laboratories. "We didn't stop teaching for a single day", says the university's rector, Stanislav Marijanovic.

So far, the University of Zagreb, which, with 42,000 students, is Croatia's largest university, and is also distant from the front line, has escaped serious damage. But it is suffering from the brain drain that has affected the whole country, with an estimated 1,800 Croatian scientists and engineers now working abroad.

Research in many fields is still proceeding, often helped by foreign collaborators.
But Sibela Jelaska, a professor of molecular biology at Zagreb's Rudjer Boskovic Institute, complains that young people no longer consider doing a PhD in Croatia. "Why should they?" she asks. "We don't even have equipment for sequencing DNA in our labs."

As a result of the war, much international financial support for research has been withdrawn. The European Communities (EC) have frozen Croatia's participation in the PHARE programme, which finances the restructuring of post-communist countries such as Poland and Hungary.

According to Jean Luis Blanc, an EC official, it is Croatia's involvement in the war that has ruled out any research support from the EC. Croatia's science and higher education minister Branco Jeren sees it differently. He claims that opportunities for collaboration have been unfairly prejudiced by international sanctions being enforced against Serbia.

Others claim that restrictions on helping Croatia are now justified by Croatia's own conduct in the war. But Jeren is looking to the future. In particular, he is preparing a new research system to replace that inherited from the communist regime when it handed over power in 1990.

Before that, Yugoslavia had lacked sufficient funding to establish modern research facilities, and had no coordinated science policy. Few formal procedures existed for linking researchers and industry. Nor was there a system for creating links between university departments, or with researchers from other countries.

Jeren, a physicist who has been minister since February, is now planning substantial changes. Two new laws are expected to be approved by parliament later this month. One, a Science Act, will enable research institutes to shift from self-management to a more efficient and competitive system of administration.

The second, a Higher Education Act, will create similar changes in universities, allowing them to establish management hierarchies and to place real power in the hands of deans and rectors. The act will also limit student places, and allow universities to select the most talented students by raising entry requirements. Jeren says he is keen to support Croatia's young scientists by allocating 12 per cent of his research budget to a "new blood programme".

Many foreign countries, including some within the EC, have been reluctant to offer anything more than humanitarian aid to Croatia because of its conduct in the war. Several, however, are continuing to provide assistance to individual scientists. And Ger-

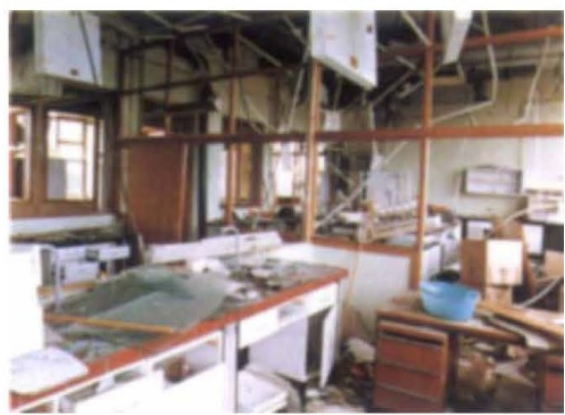

Bomb damage at the University of Osijek

many has now gone further by offering direct support for Croatia's efforts to restructure its science.

Germany's role has historical roots. As a country with traditional links to the region - as well as a desire to increase its influence in both cultural and educational matters Germany was the first to recognize Croatia as an independent state in 1991

It is partly motivated by direct self-interest. Germany is keen to stem the flood of Croatian refugees by helping to secure a stronger economy in Croatia. And, says Dieter Nentwich, head of the International Bureau in Jülich, this requires a strong science base.

The bureau, which is part of the German research ministry, currently supports around 15 scientific and technological collaborations with Croatia. These allow about 50 Croatian scientists at any one time work for a average of three months in a German research institute.

The bureau is now seeking a more direct influence on Croatia's research structure, and has offered to review the way its science is organized. According to Nentwich, the goal would be to make detailed recommendations on how research could be most efficiently funded, and on ways of encouraging the transfer of technology from laboratories to industry.

Croatia has not yet formally responded to Germany's offer. Croatian officials say they are likely to accept. But before doing so, they want to see the results of a similar exercise already being carried out in Slovenia, the wealthiest of ex-Yugoslavia's successor states's, which is expected by the end of the year. They also want to ensure strong representation of Croats on the proposed evaluation committee.

At present, uncertainties created by the most recent outbreak of fighting have led the bureau to hold back on its offer of help. Bureau officials say they are only prepared to act when the situation becomes "politically stable" - that is, when the war has ended.

But, even as Germany itself holds back. not everyone is standing still. The Rudjer Boskovic Institute, Croatia's largest research institute with 400 scientists working in its laboratories, is planning an internal reorganization. The German influence is clear. The institute's director, Krunoslav Pisk, says that its aim is "to be structured like a Max Planck Institute".

Robert Unterhuber 